\title{
THE RIGHT TO MENTAL HEALTH IN BRAZIL AND THE SILENT PANDEMIC
}

Taísa Maria Macena de Lima ${ }^{1}$

Maria de Fátima Freire de Sán

\section{Abstract}

This text focuses on the psychological repercussions of the Covid-19 pandemic on mental health. Repercussions that tend to endure in the post-pandemic world. The background of this article is the Brazilian law, and it develops in two parts. The first centered on the legislation hierarchically inferior to the Constitution to protect mental health, and the second focused on reaching the silent pandemic, that is, the mental illness resulting from traumas generated by the new coronavirus pandemic.

\section{Keywords}

Disability. Right to health. Pandemic. Mental health.

\section{Summary}

1. Introduction. 2. The Protection of Persons with Mental or Intellectual Disabilities in the Brazilian Legal System. 2.1. Analysis of the Statute of Persons with Disabilities and the Civil Code; 2.2 The Brazilian Law on the Rights of People with Mental Disorders. 3. Mental Health and Pandemic. 4. Conclusion. References.

1 Professor of Law at Pontifical Catholic University of Minas Gerais (Brazil). Former DAAD Scholar. Advisor to KAAD. Labor Judge.

${ }^{2}$ Professor of Law at Pontifical Catholic University of Minas Gerais (Brazil) . Researcher at the Center for Studies in Bio-law - CEBID. Lawyer. 


\section{INTRODUCTION}

The world is experiencing the Covid-19 pandemic, caused by the new coronavirus. So far, one only knows that the new virus has emerged in China in late 2019. One more pandemic that brings humans a great ordeal, as did the Black Death in the 14th century and the Spanish Flu in the early 20th century.

Other epidemics have plagued humankind. However, the Black Death has become one of the most significant phenomena of the Middle Ages due to its magnitude. It caused the death of more than a quarter of the European population. The Spanish Flu pandemic in 1918/1920 (which did not appear in Spain, but probably in the United States of America), in gross numbers, killed more people than the Black Death and more than AIDS today. ${ }^{3}$

The past experiences were not enough to prevent new outbreaks, epidemics, and pandemics. Not even to prepare humanity to face new, highly contagious diseases. On the contrary, the way of life in the 21st century favors the fast spread of illness as a result of natural habitats alterations which disrupt the ecological balance and create a gateway for new diseases, of the precarious living conditions in developing countries, and above all, of the increasingly globalized world, where the movement of people, nonhuman animals, goods, and services is much simpler.

Covid-19 took everyone by surprise, despite the fact that the conditions for the emergence of new outbreaks that can evolve to the point of being qualified as a pandemic are clearly recognizable. The first indications were ignored and only on March 11, 2020, the WHO recognized and declared its existence, apologizing for underestimating the global situation. Many national governments still hesitate to admit the seriousness of the disease and the lethality of the invisible enemy: 'This coronavirus pandemic resembles the flu in the mode of transmission, which is from person to

${ }^{3}$ BARRY 2020. 
person, by inhaling droplets emitted by someone infected and tiny aerosol filled with the virus. $[\ldots]^{14}$

When causing disease in the body, the coronavirus does not only compromise physical health; it indirectly affects the population's mental health, reaching, without distinction, those who were contaminated and those who were not.

Naturally, many psychological symptoms and sociability problems are typical and expected consequences of an abnormal situation. After all, people could have not remained indifferent to such radical changes or could have adapt to them so quickly.

It is possible to align several effects of the pandemic on people. Firstly, fear of becoming ill, transmitting the disease, and dying; the death of close ones; the lack of means of subsistence; unemployment; discrimination based on illness; the lack of contact with family, caregivers, and friends. In addition to fear, feelings of helplessness in the face of events, irritability, anguish, and sadness are recurrent.

Such sensations may go beyond normality and evolve to some sort of mental disorder, compromising the present and the future. Among the most vulnerable to this silent pandemic are ones who contract Covid-19, either hospitalized or not; those who are at higher risk from coronavirus, such as the elderly, people with disabilities, pregnant and lactating women; and health professionals who deal directly with infected patients. ${ }^{5}$

Given this reality, the present text focuses on the psychological repercussions of Covid-19 pandemic on mental health. Repercussions that tend to endure in the post-pandemic world. The background of this article is the Brazilian law, and it develops in two parts. The first centered on the legislation hierarchically inferior to the Constitution to protect mental health, and the second focused on reaching the silent pandemic, that is, the mental illness resulting from traumas generated by the Covid-19 pandemic.

${ }^{4}$ OSTERHOLM; OLSHAKER 2020, 11.

5 PFEFFERBAUM 2020. 


\section{THE PROTECTION OF PERSONS WITH MENTAL OR INTELLECTUAL DISABILITIES IN THE BRAZILIAN LEGAL SYSTEM}

A complex of legal rules hierarchically inferior to the Federal Constitution outlines the panorama of protection of the rights of persons with mental or intellectual disability in Brazil. The Civil Code (2002), the Statute for the Persons with Disabilities (2015) and Law No. 10.216 / 2001, which provides on the protection and rights of people with mental disorders, and redirects the mental health care model.

To understand this legislative framework, we will undertake, together, the analysis of the Civil Code (CC) and the Statute of the Persons with Disabilities (EPD) and, subsequently, we will study the compatibility of the EPD with Law No. 10.216 / 2001.

\subsection{Analysis of the Statute of Persons with Disabilities and the Civil Code}

By enacting Law No. 13,146, of July 6, 2015, that establishes the Brazilian Law for the Inclusion of Persons with Disabilities (Statute for Persons with Disabilities), Brazil, which is a signatory to the Convention on the Rights of Persons with Disabilities (New York Treaty), gave it the effectiveness of a constitutional norm.

The legislative changes, brought by the Statute, extend to different sectors of life, aiming at breaking down barriers of social exclusion. The Statute, also known as the Social Inclusion Law, was created from a new understanding of disability, be it physical, mental, intellectual, or sensory. If before we sought to offer people with disabilities instruments and mechanisms so they could adapt to the 'normal world', now the focus is on transforming the world to welcome them.

It is essential to redesign the profile of persons with disabilities in the context of legal capacity. The Law undoubtedly seeks to recognize the autonomy of people with disabilities, recognizing them as legal subjects. 
However, in doing so, it assigned greater responsibilities to them, presuming that, in any situation, the human being is the author of their destiny.

Nevertheless, is the human person is always capable of self-government? Will individuals invariably have an understanding of the world and selfawareness for decision-making?

This higher concern over people's autonomy, especially vulnerable people, is explained by the transformation of the juridical phenomenon: The law has become less focused on the roles that people play throughout life, to focus on the concrete human being. The discussion about the human person's dignity is based on this shift of direction - the affirmation of their autonomy built on discourse.

Discursive autonomy repels the traditional technique of subsumption in the interpretation and application of legal norms, that is, it does not adjust to all or nothing situations; to yes or no, nor does it fit binary solutions. This issue was raised in the book A Capacidade dos Incapazes that proposed a re-reading of the theory of disabilities in the context of mental health:

The proposition is to think of hermeneutical possibilities that do not establish priority and hierarchy relations. Interpreting the Law as a rule and exception would imply, in advance, bringing solutions that do not observe the contexts and contours of a specific case. With this, we are not advocating the suppression of total incapacity of Private Law, but promoting its reinterpretation, no longer identifying it as an absolute presumption. This means, albeit potentially, giving a voice to the disabled people. ${ }^{6}$

'SÁ; MOUREIRA 2011, 138. 
The proposition of the Statute is, admittedly, to give a voice to people with mental and intellectual disabilities who, for a long time, were socially stigmatized, and although had their rights declared by law, as a rule, were not recognized as having the autonomy to exercise them. It turns out that the Statute, like many other 'well-intentioned' laws, fell into the trap of abstraction and generality.

According to art. 2 of the Statute, the disabled person is 'the one who has a long-term physical, mental, intellectual or sensory impairment, which, in interaction with one or more barriers, may restrict their full and effective participation in society on equal terms with other people'.

In the head of art. 6 the Statute provides that disability does not affect the person's full civil capacity. The great revolution brought by it is the recognition of full legal capacity, understood as the capacity to exercise your rights, the possibility to act personally upon them, in all aspects of life. Such a statement is based on the language used in the items of art. 6 itself, in which the verb 'exercise' is linked to several existential situations (sexual and reproductive rights; right to decide on the number of children; right to family and to family and community coexistence; right to custody, third party custody, guardianship, and adoption, as adopter or adopted). Others cannot exercise such rights, even if the disable person is under guardianship. Legal capacity, as ownership of rights, has never been denied to people with disabilities in Brazilian codified Civil Law. But when one of them was interdicted and declared totally incapacitaded, the very personal rights, which could not be exercised by representation and, also, could not be exercised by the totally incapacitated person, had their content emptied. 'This meant a limitation of the legal capacity itself because 'a right' that can never be exercised, a right is not. On the other hand, conferring ex-ante exercise capacity to human beings who, due to a severe mental and intellectual disability, do not have real conditions of self-government, also leads to the exhaustion of personal rights of strict nature. In this case, it is not the legal order or social barriers that hinder the exercise of the right, but the peculiar condition of the legal subject themselves, and this was not considered in the drafting of the Statute. 
During the Statute enforcement, it is possible to identify three positions regarding the capability to practice the acts of civil life: (i) the disabled person is always fully capable, (ii) the disabled person may be declared relatively incapacitated, eventually, according to art. 4, clause III of the CC, as the disability may be the temporary or permanent cause, which prevents them from expressing the will, (iii) the person with a disability, as long as is not able to manifest or elaborate a 'weighted will', can be declared relatively incapacitated, according to art. 4, clause III of CC.

That first position results from a more literal interpretation of the main body of art. 6 of the Statute. The reading of its paragraphs acknowledges the disabled person the possibility to marry, establish a stable union, exercise sexual or reproductive rights, exercise the right to decide on the number of children and have access to adequate information on reproduction and family planning, exercise the right to family and family and community coexistence and, finally, to exercise the right to custody, third party custody, guardianship, and adoption, as an adopter or adopted, on an equal basis with other people.

Once again, we highlight the use of the verb exercise in the wording of art. 6 , revealing the intention to ensure the legally guaranteed possibility for the person with a disability to practice legal acts personally. Besides, the Statute made changes to articles 3 and 4 of the Civil Code, excluding any type of disability among the causes of absolute incapacity and relative incapacity. Consequently, according to the new Brazilian Civil Code system, only people under the age of sixteen are absolutely incapacitated. As for the relatively incapacitated, the list is restricted to those over sixteen and under eighteen; the habitual drunkard and people with addiction to toxic substances; to those who, due to temporary or permanent reasons, are unable to express their will and to the prodigals.

Despite this, the Law has maintained the possibility of guardianship for people with disabilities, which has caused some perplexity. According to this theory, the Statute would have created a new type of guardianship, the guardianship of capable people. 
The second position argues that it is possible to recognize the relative incapacity of people with disabilities, according to art. 4, clause III of the CC, when, and only when, the disability is the temporary or permanent cause that prevents a person from expressing their will. In Flávio Tartuce's words:

All persons with disabilities who were addressed in the previous command have become, as a rule, fully capable before the Civil Law, which aims at their total social inclusion, in favor of their dignity. By valuing dignity-freedom, dignity-vulnerability is left aside.

Occasionally, people with disabilities may be considered relatively incapacitated, under some framework of art. 4 of the Civil Code also amended now. ${ }^{7}$

There is no difficulty in including other types of disability in the assumptions of art. 4, clause III of CC: a deaf person, a person with Alzheimer's, a person with autism, a person with a mental disorder, as long as these medical conditions are what is preventing the expression of the will. The problem is to understand how a person who cannot even express their will have the status of relatively incapacitated. After all, the relatively incapacitated is by definition someone who can perform some acts under the assistance of others, such as parents, non-parental guardians, or guardians, and under certain circumstances can even perform alone some legal acts.

Finally, the third position seeks to reinterpret a hypothesis of incapacity already known in Brazilian law: temporary or permanent cause that prevents the

${ }^{7}$ TARTUCE 2018, 132. 
person from expressing their will, which came from the absolute incapacity model and moved to the relative incapacity model, from the entry into force of the Statute.

According to Nelson Rosenvald, the Statute mitigates, but does not annihilate, the theory of disabilities in the Civil Code:

People with disabilities subjected to guardianship are removed from the list of absolutely incapacitated of the Civil Code and sent to the catalog of relatively incapacitated, with a renewed terminology. The new wording of clause III, of art. 4 (Law No. 13,146 / 15) sends to the confines of relative incapacity "those who, due to transitory or permanent reasons, are unable to express their will". This reveals the qualitatively different intervention of the Statute of the Persons with Disabilities in the theory of disabilities: The medical and welfare perspective of labeling as incapacitated the one who exhibits a psychological or intellectual insufficiency is abolished. Correctly, the legislator chose to locate the incapacity in the set of circumstances that express the real and lasting impossibility of the person's willingness and understanding, and that therefore justify the guardianship, so the human being, in all its complexity, is not reduced to the clinical scope of psychological or intellectual incapacitation. That is, the watershed between capacity and incapacity no longer lies in the characteristics of the person, but in the fact that they find themselves in a situation that prevents them, for whatever reason, from conforming or expressing their will. The criterion of the impossibility for a citizen of legal age to 
make informed and autonomous decisions about his or her person or property or to adequately express or execute them prevails.

The mentioned criterion broadens the meaning and scope of the cause of disability foreseen in art. 4, item III of the CC: according to it, it is not only a question of externalizing the will; the impossibility for the person of legal age to make informed and autonomous decisions on patrimonial or existential issues, or both, is raised to criterion to define whether the person is capable or is relatively incapable. The capacity to exercise a right, therefore, requires a qualified will. If such a qualified will does not exist, even if the person with disabilities is able to interact socially, from a legal point of view he or she is not able to express the will ('weighted will'). Consequently, Law No 13.146/15 would not have created the new category of 'capable persons under guardianship'. Every person with disabilities under guardianship would be relatively incapacitated.

The idea of giving legal relevance to the so-called "weighted will" of people with mental or intellectual disabilities is in line with what has been already advocated in the book: A Capacidade dos Incapazes:

Taking the Law seriously also means ensuring the constitutional guarantees of the process in the construction of a judicial decision that concerns the limitation of the individual's autonomy to perform acts that refer to their own life as a subject of rights. The effective participation of the person under protection in the guardianship process must be safeguarded, to the point of even knowing the possibility of its limits.

${ }^{8}$ ROSENVALD 2015, p. 6.

9 SÁ; MOUREIRA 2011, 143. 
Now, any of these theories cannot ignore the real fact: disabled people, when affected in their judgment, will need the help of others to exercise rights of patrimonial and existential nature. This assistance may occur along the lines of assistance or representation, depending on the level of discernment of the person under guardianship. In fact, this is what Iara Antunes de Souza defends when she proposes to 'remove the logic that the absolutely incapacitated is represented and the relatively (in) capacitated is assisted, relegating to the recognition of the lack of discernment, by a multidisciplinary mental health team, the application of the necessary measure to promote personality'. ${ }^{10}$

Although the legislation defines who is fully capacitated, relatively incapacitated and absolutely incapacitated, it is not able to attribute discernment to those who, due to personal conditions (health and age) do not have it, or have it to a limited extent. In trying to give greater dignity to people with disabilities, the Statute has created other problems, failing to point out solutions.

\subsection{The Brazilian Law on the Rights of People with Mental Disorders}

Moving on to examining Law No. 10.216/2001 that provides for the protection and rights of people with mental disorders and redirects the mental health care model, it is essential to inquire about its compatibility with the Statute of the Persons with Disabilities.

Explaining: Law No. 10.216/01 provides for the possibility of hospitalization without the patient's consent, while the Statute of the Persons with Disabilities brings, in its art. 11, the prohibition of 'forced institutionalization'.

${ }^{10}$ SOUZA 2016, 297. 
At first glance, the two laws are incompatible; however, one cannot mistake a treatment that requires temporary removal of people from their family and social environment for asylum-based policies rejected by the Brazilian legal system. The analysis of the legal norm that redirects the mental health care model reveals that its objectives converge with the aims of the Statute in that both aim to ensure the rights of people with mental and behavioral disorders.

In the search for the protection and rights of people with mental disorders, Law No. 10,216 of April 6, 2001, brought relevant norms that must be worked on carefully, especially given the profound controversies it raises. The first aspect worth emphasizing is set out in art. 4. According to it, 'Hospitalization, in any of its modalities, will only be indicated when the extra-hospital resources had proved insufficient'. This article translates the legislative option to limit psychiatric admissions, inspired by a movement in Psychiatry that defends that the interaction of the patient in society is considered part of the process of treatment and, or cure. Therefore, its segregation from social, professional, and family environment would only be recommendable from a medical and legitimate legal point of view, in extreme situations.

On the other hand, we must not forget that such extreme situations happen and are not that rare. It is clear the attempt of the Law to ban for good exclusionary and segregating treatments from Brazilian society. However, there are no absolute truths. Even the most advanced or recent scientific theory is not the definitive word. The interpreter of the legal norm (legal professionals, medical professionals, and even ordinary citizens) may face situations in which the patient is in dire need of hospitalization. The choice for that type of Psychiatry has influenced the mental health system structure, from one extreme to the other. Naturally, banning asylum-based hospitalization that demanded a large number of beds resulted in a considerable reduction of places in psychiatric hospitals today, which is, for many, compensated by the existence of Psychosocial Care Centers. Law $\mathrm{n}^{\circ} 10.216 / 01$ provides for three types of hospitalization: voluntary, which takes place with the patient's consent; involuntary, done at the request 
of a third party, without the consent of the patient; and compulsory, carried out by judicial order (sole paragraph of art. 6). In all situations, psychiatric hospitalization will only occur upon a detailed medical report characterizing the reasons (art. 6, main body).

Voluntary hospitalization is certainly the least problematic one. Of course, each concrete case will show how easy or difficult it is for the family to obtain the patient's consent. There are those who are clearly aware of the need for treatment and agree to hospitalization, even if they are patients with recurrent admissions.

Another issue concerns what we call non-consensual hospitalization provided for in two modalities in art. 6: involuntary hospitalization and compulsory hospitalization.

In such cases, there is a flagrant clash of wills. The patient does not want hospitalization, but the family does not see any solution other than that. In this scenario we could envision the following situations: i) If the patient has discernment and does not want to be hospitalized, in principle, there is no way the family could do so; ii) But, assuming the existence of discernment, even if the patient does not want to be hospitalized, the family could do so if the person with mental disorder put lives of others at risk; iii) And, in case the patient has no discernment, and their actions threaten their own life, lives of others, or both, hospitalization is possible. All of these hypotheses are concerned to types of involuntary hospitalization.

There are also other possibilities of tension regarding non-consented hospitalization: iv) The patient himself or even the family considers unnecessary the hospitalization determined by the State by judicial decision; v) The family considers necessary the patient's hospitalization, which is denied in a judicial decision.

The compulsory hospitalization provided for in art. 6, III, Law $\mathrm{n}^{\circ} .10 .216$ / 01, must be understood in the light of criminal law. Given the unaccountability of the person with mental disorders who has committed a crime, their acquittal is due, with the consequent application of a safety measure, consistent with hospitalization and treatment. The enforceability of the measure removes any consideration of private autonomy. 
Compulsory hospitalization - an authentic security measure aligned with Criminal Law and Criminal Procedure - must not be confused with cases in which the judge authorizes psychiatric hospitalization to meet the patient's will, upon request formulated by a relative, spouse, or interested third party. That is why it is more appropriate - even if there is a judicial intervention to use the expression involuntary bospitalization, leaving the expression compulsory hospitalization exclusively for psychiatric admissions determined in criminal proceedings.

In any case of hospitalization, whether voluntary or not, persons with mental or intellectual disabilities hold rights that must be respected (art. 2 of Law $n^{\circ}$. 10.216/2001):

I - have access to the best treatment in the health system, in line with their needs,

II - to be treated with humanity and respect and in the exclusive interest of benefiting their health, aiming to achieve their recovery by inserting them in the family, work, and community, III - be protected against any form of abuse and exploitation,

IV - have a guarantee of confidentiality of the information provided,

$\mathrm{V}$ - have the right to medical presence, at any time, to clarify the need or not for their involuntary hospitalization,

VI - have free access to the available means of communication,

VII - receive more information about their disease and treatment,

VIII - be treated in a therapeutic environment by the least invasive means possible, IX - be treated, preferably, in community mental health services. 
It is worth mentioning that even in a normative device that deals with mental illnesses, the patient's free and informed consent is relevant when making decisions. We do not see how to be otherwise because of the range of situations that may involve different degrees of discernment. Thus, since the patient has discernment to expresses their will not to be subjected to hospital admission and once they do not put lives of others at risk, even if exposing their own lives to risk, from a technical-legal point of view, the family decision for hospital admission is not legitimate. On the other hand, when there is no discernment, and the lack of it leads the individual to put oneself at risk, even if it does not cause danger to a third party, the family decision of hospitalization is legitimate.

It is also configurable the clash between patient and, or family and the state (non-consensual admission).

Finally (item v), the hypothesis in which the family considers necessary the hospitalization of the patient, but it has been denied in a judicial decision. This case supposes a request made by the family or by a third party, in the involuntary hospitalization model. The attribution given to the magistrate to determine the hospitalization contains, implicitly, the possibility of denying it, if they consider the legal requirements absent.

However, the Law allows the family to decide for hospitalization, without judicial permission, provided that it is preceded by authorization by a doctor duly registered with the Regional Council of Medicine of the State where the establishment is located (Article 8, caput of Law $n^{\circ} 10.216 / 2001$ ) and, within 72 hours, the hospitalization is communicated to the State Public Prosecutor's Office by the technical manager of the establishment where it occurred, and this same procedure must be adopted upon discharge (paragraph 1, art. 8).

Law $n^{\circ} .10 .216 / 2001$ also addresses situations of "habitual drunkenness and addiction to toxic substances", since addictive substances can reduce the individual's judgment, affecting his mental health.

3 MENTAL HEALTH AND PANDEMIC

Human(ities) and Rights | GLOBAL NETWORK JOURNAL | Vol.2 (2020) Issue 2 |56 
The pandemic has established a new way of life, as social isolation and quarantine are fundamental to breaking the chain of infection. The first is the attitude of voluntary withdrawal from social coexistence, in order to reduce the speed of contamination and avoid the collapse of the health system, public and private; the second aims to separate the infected from healthy people and the third, quarantine, means to separate and restrict the movement of individuals already exposed to situations with potential for transmission.

Non-drug measures to fight an infection that tears human body organs become a factor of aggravation or even appearance of mental illnesses.

If, on the one hand, all these measures are essential to protect the population, on the other hand, they affect the psychological and emotional health of people, who are deprived of the social environment to which they were accustomed.

Transferring personal contact to digital platforms reduces social interaction while seeing and hearing. It also reduces considerably touch and smell perceptions, bringing the feeling of greater emotional isolation:

In the current pandemic, the home confinement of large swaths of the population for indefinite periods, differences among the stay-at-home orders issued by various jurisdictions, and conflicting messages from government and public health authorities will most likely intensify distress. A study conducted in communities affected by severe acute respiratory syndrome (SARS) in the early 2000 s revealed that although community members, affected individuals, and health care workers were motivated to comply with quarantine to reduce the risk of infecting others and to protect 
the community's health, emotional distress tempted some to consider violating their orders. ${ }^{11}$

Throughout the world, and in Brazil it is no different, health professionals, who are at the forefront of the fight against COVID-19, whether doctors, nurses, nursing technicians, physiotherapists, nutritionists, psychologists, have been facing impacts on their physical and mental health. Work overload (physical, cognitive and psychological) is accompanied by the increase in the requirements for decision-making about life and death worsen by a scenario of resources scarcity, both to treat the patient and to protect professionals; in uncertainty as to the effectiveness of available treatments and medications and the need to follow the evolution of technique and science regarding the new disease:

Someone might argue that technical knowledge will provide the answer. Yes, that illusion may exist, but someone still has to say which technical criteria one will use for making the decision. Will there be a technical decision that is morally neutral? Certainly not. Although not always explicit, even the most complex algorithm has moral choices intrinsic to it. Yet, the false neutrality of technicalbased decision makes anguish almost inescapable. The conflict between reality on the one hand and the individual values and moral ideals inherent to training and professional practice on the other expresses the moral burden that becomes even more relevant in situations of a scarcity of resources necessary for this practice, as we live very

11 PFEFFERBAUM 2020, 2. 
often in Brazil, and now aggravated by the pandemic. $^{12}$

To minimize the moral burden, shared decisions with the support of bioethics committees, composed of specialists from different areas, including law, are recommended. After all, there is always the risk of doctors being civilly held responsible for dissatisfied patients or their relatives.

One of the important aspects of the effectiveness of the doctor-patient relationship is the accomplishment of the Term of Free and Informed Consent, which seems to be a marker of the extension of the doctor's civil responsibility. It is a document by which the patient manifests consent or dissent with a specified treatment. In the pandemic, however, it will not always be properly formalized, which does not exclude the ethical and legal duty of the doctor to seek, to the greatest extent possible, a dialogical relationship with the patient.

Besides, all health professionals directly experiencing the pandemic fear being contaminated and becoming a vehicle of contamination of those close to them. The isolation of these professionals is common, as they tend to distance themselves from families and friends.

Another group that demands special attention is the elderly. Vulnerability to Covid-19, in itself, is already a cause of fear and anguish, worsened when, given the scarcity of resources for ICU care, the elderly are victims of age discrimination, that is, they are overlooked to favor younger patients. In this context, it is not much to state that living longer can become a punishment. When the pandemic started, the media reported several cases of older people being sidelined under the argument that it was up to the old to make room for the new. The reports even subliminally suggested that the renunciation of ventilators by the elderly was an act of altruism that should be followed by other older people.

12 REGO; PALÁCIOS 2020. 
It was reported that a ninety-year-old Belgian woman infected with the new coronavirus gave up the ventilator so it could be used on young patients. Before the impossibility of her daughter's visit, she left the following message: 'you can't cry. You did everything you could. I had a good life'. ${ }^{13}$ It is believable that this lady chose death. Belgium is a country, like the Netherlands, Switzerland, and others, where the awareness of death is very strong, and these choices are legitimate. However, one cannot encourage the insinuation that older people should take 'altruistic attitudes' to benefit others, giving up their own lives, to the argument of having lived longer. It is cruel and nonjuridical to talk about the dispensability of older people's lives.

It is not too much to remember that the 1988 Constitution of the Republic provides specific rights for the older population, under its arts. 229 and 230. The national policy for older people is defined in Law No. 8.842/1994 and the Statute of the Elderly (Law No. 10.741/2003) disciplines the rights ensured to the older people, establishing priorities in public policy and providing mechanisms for the exercise of citizenship.

The measures taken must be motivated, observing the scientific evidence with clarity and transparency. Beyond biological care, care with the biography of elderly patients is also necessary, as well as psychological support.

If the pandemic creates conditions for mental and emotional disorders, it also aggravates pre-existing conditions. People with intellectual and mental illness face additional challenges, as they need even more care from their caregivers. Many of them need help with eating, dressing, personal hygiene, and moving around, even at home. When the economic vulnerability is added to this picture, many material needs are no longer met by either the suspension of certain services, the lack of certain goods, or both.

There are people with disabilities, as well as elderly people, who live in institutions, who have a high risk for Covid-19. The most common measure

${ }^{13}$ A TRIBUNA 2020. 
for breaking the chain of contamination is the limitation of contact with relatives. However, such a decision may mean them becoming unprotected due to abuse or negligence on the part of the institutions. The news about what happened in an asylum in Dorval, near the city of Montreal/Canada, was perplexing. Elderly people were left to their own devices amidst the spread of the coronavirus. When the employees of the health care home witnessed the death of many people who lived there, they interrupted their work and abandoned the patients, without any communication. According to the news, those who survived were found in inhuman and degrading conditions, hungry and thirsty, unhygienic, and scattered on the floor. Two dead bodies left in the beds. ${ }^{14}$

How to preserve mental health living in adversity and abandonment? Brazil is a continental country, with deep social and economic inequalities, besides ethnic and cultural plurality. In this context, the situation of the various indigenous tribes should not be ignored.

In the Upper Xingu, when someone from the Kuikuro indigenous people dies, their body is prepared to enter the world of the dead. In the ritual, one must embrace the dead, adorn, and paint their body with ancestral designs. The farewell solemnity is necessary so that whoever departed may continue to be respected in the afterlife. The consequence of a failure to perform the ritual is a life of shame in the other world. In the State of Mato Grosso, it is the custom of the Xavante people of Aldea Guadalupe to open the coffin several times and touch the dead person. It is a demonstration of respect and pain for their departure.

Among the Yanomami people, the dead should never be put under the soil. The farewell rituals in the villages last for months and aim to give the deceased time and strength so they can die for the community and lead a life without evil in another world. For a month, the body remains isolated to be purified and then cremated. They keep the ashes until one makes a new celebration to remember the life and virtues of the person who has

${ }^{14}$ CRAVEIRO 2020. 
gone. Afterward, the ashes are diluted in a banana porridge to be shared so the dead is forgotten and their soul set free. Those who remain can move on.

Each society has death rituals for the farewell of the dead. Many are born from the hope that, once performed, meeting the loved ones again in another world will be possible someday; others are born out of the sheer need to accept the ultimate loss. Whatever the causes determine or inspire them, the rituals are relevant to understanding death as the natural flow of life. In this process of acceptance, grief has to be experienced and respected. The pandemic has interrupted the grieving process, and that is very painful. Perhaps it is even worse for the indigenous people because the ritual maintains the strength of the community.

Adequately saying goodbye to your dead and experiencing the grieving process are essential to overcome the pain of loss and preserve emotional and psychological sanity. The Covid-19 pandemic has not only robbed people of physical health and life but also of mental health.

\section{CONCLUSION}

The first Brazilian Civil Code, dated 1916, referred to people with mental disorders as 'insane of all kinds' to qualify them as absolutely incapacitated. The 2002 Civil Code - which came into force in 2003 - brought changes in the Theory of Disabilities to make it possible for people with mental or intellectual disabilities to be legally fully capable, relatively incapable, or absolutely incapable.

Under the Statute of the Persons with Disabilities, mental and intellectual problems are no longer a cause of incapacitation. Thus, in just over a century, there has been a profound change in the status of this group of legal subjects. Dignity-vulnerability has been replaced by dignity-autonomy. Conferring greater autonomy cannot have the effect of subtracting the legal protection these people need, whatever their legal status is.

It is impossible not to mention that, by privileging dignity-autonomy, the Statute reacted to the abuses committed by caregivers of people with 
mental, emotional, and intellectual disorders. However, the autonomy to decide on one's own life requires discernment to some degree.

The Brazilian Law on the Rights of People with Mental Disorders (Law $\mathrm{n}^{\circ}$. 10.216 / 2001) - which predates the Civil Code of 2002 and the EPD sought to redirect the welfare-based mental health care model, in an attempt to emancipate and simultaneously protect; it guarantees the patient's right to all types of care, from the simplest to the most complex one, not excluding the possibility of non-consensual hospitalization. This entire legal framework, although relevant for social inclusion, will not be enough to face the silent pandemic, that is, the growing mental illness resulting from the trauma caused by Covid-19.

According to article 196 of the 1988 Federal Constitution, health 'is a right of all and a duty of the State and shall be guaranteed by means of social and economic policies aimed at reducing the risk of illness and other hazards and at the universal and equal access to actions and services for its promotion, protection and recovery'. Thus, just as the Brazilian State must adopt policies to combat the new coronavirus, it cannot neglect this other pandemic, which is already evident and tends to endure in the postpandemic world.

In case of omission by the State, as the administrator, the effectiveness of the right to mental health - as disciplined in the Civil Code, the Statute of the Person with Disability and Law No.10.216/2001 - will be deeply compromised, leaving no other way but to take the conflict to the Judiciary. Brazil - with its cultural, socioeconomic, and ethnic diversity - is demanding specific public policies for different groups, which can prevent the judicialization of health. A phenomenon that has become very frequent and that can be intensified with the new problems arising from the two pandemics - the visible one and the one that hides behind the first. 


\section{REFERENCES}

BARRY, John M, “A grande gripe: a história da gripe espanhola, a pandemia mais mortal de todos os tempos", in Alexandra Raposo et al. (eds.) Trans, Rio de Janeiro, 2020.

BRASIL, Law no. 10,211 of March 23, 2001, http://www.planalto.gov.br/ccivil 03/leis/LEIS 2001/L10211.htm

BRASIL, Law no. 10,406, of January 10, 2002, http://www.planalto.gov.br/ccivil 03/leis/2002/110406compilada.htm

BRASIL, Law no. 13,146, of July 06, 2015, http://www.planalto.gov.br/ccivil 03/ ato2015-

2018/2015/lei/113146.htm

BROOOKS, S. K., WEBSTER, R. K., SMITH, L. E., WOODLAND, L., WESSELY, S., GREENBERG, N., \& RUBIN, G. J., "'The psychological impact of quarantine and how to reduce it: Rapid review of the evidence", The Lancet, 395, 912-920.

https://www.thelancet.com/pdfs/journals/lancet/PIIS0140$\underline{6736(20) 30460-8 \text { pdf accessed }}$

CRAVEIRO, Rodrigo, "A face mais cruel da pandemia: abandono de idosos choca o mundo", Diário de Pernambuco, URL: https://www.diariodepernambuco.com.br/noticia/mundo/2020/04/aface-mais-cruel-da-pandemia-abandono-de-idosos-choca-o-mundo.html.

JUCÁ, Beatriz, "O coronavírus está quebrando a nossa crença, o luto imposto aos povos indígenas na pandemia", El País, URL: https://brasil.elpais.com/brasil/2020-07-11/o-coronavirus-estaquebrando-a-nossa-crenca-o-luto-imposto-aos-povos-indigenas-napandemia.html?ssm=TW_BR_CM 
OSTERHOLM, Michael T.; OLSHAKER, Mark, Inimigo mortal: nossa guerra contra os germes assassinos, Rio Janeiro, 2020.

PFEFFERBAUM, Betty, Mental Health und the Covid-19 Pandemic. The New England Journal of Medicine, 2020.

REGO, Sérgio; PALÁCIOS, Marisa. Saúde mental dos trabalhadores de saúde em tempos de Coronavirus. URL: https://www.arca.fiocruz.br/bitstream/icict/40659/2/Sa\%oc3\%badeMent al.pdf

ROSENVALD, Nelson, "Em 11 Perguntas e Respostas: Tudo que você precisa para conhecer o Estatuto da Pessoa com Deficiência" Boletim informativo $\quad \mathrm{MPB} A, \quad$ 13, Salvador, 2015, URL: https://www.mpba.mp.br/sites/default/files/conteudo/boletim/boletim _informativo 13 pdf accessed 18 July 2020.

SÁ, Maria de Fátima Freire de; MOUREIRA, Diogo Luna, A capacidade dos incapazes: saúde mental e uma releitura da teoria das incapacidades no direito privado, Rio de Janeiro, 2011.

SÁ. Maria de Fátima Freire de; SOUZA, Iara Antunes de, "Termo de consentimento livre e esclarecido e responsabilidade civil do médico e do hospital", in Nelson Rosenvald et al. (eds.) Responsabilidade civil e medicina, Indaiatuba, 2020.

SOUZA, Iara Antunes de, Estatuto da pessoa com deficiência: curatela e saúde mental, Belo Horizonte, 2016.

TARTUCE, Flávio, Direito civil: lei de introdução e parte geral I, Rio de Janeiro, 2018. 